\title{
Effects of Supplementation of lonized or Chelated Water-Soluble Mineral Mixture on the Live Performance, Nutrient Digestibility, Blood Profile, Egg Quality, and Excreta Microbiota of Laying Hens
}

-Author(s)

\author{
Upadhaya SD \\ Lee BR' \\ Park JW' \\ Kim $\mathrm{IH}^{\prime}$
}

Department of Animal Resource and Science, Dankook University

\section{ABSTRACT}

In total, 216 Hy-Line brown laying hens (40-week-old), were used in a 5-week experiment to evaluate the effects of ionized or chelated water-soluble mineral mixture supplementation on live performance, nutrient digestibility, blood characteristics, egg quality, and excreta microbiota. Layers were randomly assigned to one of three dietary treatments with 12 replicates of six adjacent cages each. The dietary treatments consisted of: 1) CON (basal diet + normal tap water), 2) T1 (CON+0.5\% ionized mineral mixture in tap water, $\mathrm{pH} 3.0)$; and 3) $\mathrm{T} 2(\mathrm{CON}+0.5 \%$ chelated mineral mixture in tap water, $\mathrm{pH} 3.0)$. Egg production tended to increase in week 1, week 3 and week 4 in the birds supplemented with T1 and T2 diet compared with CON. Moreover, the dietary supplementation of water-soluble mineral mixture improved $(p=0.02)$ eggshell thickness in week 4 and tended to improve in week 5 of the experimental period in T2 hens compared with CON. The layers fed the T1 diet presented higher $(p<0.05)$ Ca digestibility than CON hens, while the $\mathrm{T} 2$ diet promoted a numerical increase in $\mathrm{Ca}$ digestibility. Blood calcium concentration increased $(p<0.05)$ with T1 and $\mathrm{T} 2$ treatments compared with CON. The laying hens fed the T1 and T2 diets tended to present lower Salmonella and E. coli counts isolated from excreta compared with CON. In conclusion, ionized and chelated mineral mixtures had a positive impact on production performance and eggshell quality, improved Ca digestibility and blood Ca level.

\section{INTRODUCTION}

The knowledge of the factors that affect the performance and quality of the eggshells produced by commercial layers is crucial for the production of high quality eggs. Eggshell influences the economic profitability of egg production and hatchability. Eggs with damaged eggshells have been estimated to account for $6-10 \%$ of all eggs produced, which causes significant economic losses (Roland, 1988). Therefore, mineral nutrition and supplementation have been considered for the improvement of egg quality. However, the effectiveness of minerals to improve animal performance depends on their bioavailability.

For instance, ionized minerals are considered to be readily available to the body for absorption. The ionization of minerals means that the mineral has either negative or positive charge. Minerals in ionic state carry an electric charge, which allows them to readily bind with water, resulting in their easy absorption in the body.

Also, chelated minerals are said to be more bioavailable than inorganic salts because inorganic salts are reported to rapidly dissociate and freely interact with antagonists, which leads to their loss prior to absorption (Henry et al., 1992; Ward et al., 1996). However, organic mineral complexes, formed by the chelation of mineral with organic acids, amino acids or peptides, prevent minerals from interacting with 
antagonists because the minerals are bound to organic ligands through covalent bonds, which improves their bioavailability (Ward et al., 1996). The acidic status of the small intestine is necessary for the ionization of dissolved minerals (Tim O'Shea, 1998). Chelation involves the binding of a mineral ion to another component, which is usually an organic compound such as amino acids, protein, organic acids, etc.

Broilers fed chelated zinc (Zn), copper (Cu), and manganese $(\mathrm{Mn})$ showed better bone strength, skin integrity, and immune response than inorganic trace minerals (Decoux et al., 2013). Minerals have a strong influence on egg quality of laying hens. The study performed by Ceylan \& Scheideler (1999) showed that organic $\mathrm{Zn}$ is associated with better activity of the enzyme carbonic anhydrase, increasing eggshell quality, and $\mathrm{Mn}$ promotes eggshell calcification and strength.

Organic trace mineral supplementation to breeder and layer diets was shown to improve hatchability, albumen quality, and eggshell thickness (Rutz et al., 2004); however, there is less information in literature on eggshell formation. We hypothesized that ionized or chelated water-soluble mineral complex, a novel product obtained by mixing ionized minerals with organic acids and a natural extract produced from some plants, such as wild grapes and prickly pear, through Bacillus fermentation could improve the bioavailability of minerals to poultry and hence improve the production performance of layers.

Therefore, the objective of the present experiment was to determine the effects of ionized or chelated water-soluble mineral mixture on the performance, nutrient digestibility, blood profile, and isolation and enumeration of Salmonella and E. coli. in the excreta of layers.

\section{MATERIALS AND METHODS}

The experimental protocol used in this study was approved by the Animal Care and Use Committee of Dankook University. All birds used in this trial were handled in accordance with guidelines set forth by the Dankook University Committee on Laboratory Animal Care.

\section{Experimental Design, Birds, Diets and Housing}

In total, 216 40-week-old layers (Hy-LineBrown) were housed in a windowless laying house under a photoperiod of $17 \mathrm{~h}$ light: $7 \mathrm{~h}$ dark at approximately $23^{\circ} \mathrm{C}$. Layers were individually housed in cages $(20-\mathrm{cm}-$ width $\times 50-\mathrm{cm}$ length $\times 40-\mathrm{cm}$ height).
Layers were randomly assigned to one of three dietary treatments with 12 replicates of six adjacent cages each. The dietary treatments consisted of: 1) CON (basal diet + normal tap water, $\mathrm{pH}$ 6.1), 2) T1 $(\mathrm{CON}+0.5 \%$ ionized mineral mixture in tap water, $\mathrm{pH}$ 3.0); and 3) $\mathrm{T} 2(\mathrm{CON}+0.5 \%$ chelated mineral mixture in tap water, $\mathrm{pH}$ 3.0). All cages were equipped with nipple drinkers and common trough feeders. Water was provided ad libitum during the entire 5-week experimental period. The birds were fed experimental diets during the peak of lay (40 to $45 \mathrm{wk}$ of age). All diets used in the present study were formulated to meet or exceed the nutrient recommendations of the NRC (1994) and provided in mash form (Table 1).Birds were housed in the cages for seven days prior to the start of the experiment for habituation, during which the control (CON) diet was supplied.

Table 1 - Basal diet composition (as-fed basis)

\begin{tabular}{lc}
\hline Item & \\
\hline Ingredients (\%) & 50.4 \\
Corn & 18.7 \\
Soybean meal (CP, 46\%) & 10.0 \\
Wheat grain & 2.0 \\
Corn gluten meal & 5.0 \\
Wheat bran & 4.4 \\
Animal fat & 7.5 \\
Limestone & 1.4 \\
Dicalcium phosphate & 0.3 \\
Salt & 0.1 \\
DL-Met (50\%) & 0.1 \\
Vitamin premix ${ }^{1}$ & 0.1 \\
Trace mineral premix ${ }^{2}$ & \\
Calculated values & 2,904 \\
ME (kcal/kg) & 15.02 \\
CP (\%) & 0.78 \\
Lys (\%) & 0.65 \\
Met + Cys (\%) & 3.25 \\
\hline Ca (\%) & \\
\hline Providedper & \\
\hline
\end{tabular}

'Provided per kg of diet: vitamin A, 125,000 IU; vitamin D3, 2,500 IU; vitamin E, $10 \mathrm{mg}$; vitamin K3, 2 mg; vitamin B1, 1 mg; vitamin B2, 5 mg; vitamin B6, 1 mg; vitamin B12 $15 \mathrm{mg}$; folic acid, $500 \mathrm{mg}$; niacin, 35,000 mg; Ca-pantothenate acid, 10,000 mg and biotin, $50 \mathrm{mg}$.

2Provided per $\mathrm{kg}$ of diet: $8 \mathrm{mg} \mathrm{Mn} \mathrm{(as} \mathrm{MnO2}$ ); $60 \mathrm{mg} \mathrm{Zn} \mathrm{(as} \mathrm{ZnSO4);} 5 \mathrm{mg} \mathrm{Cu}$ (as CuSO4.5H2O); $40 \mathrm{mg}$ Fe (as FeSO4.7H2O); $0.3 \mathrm{mg}$ Co (as CoSO4.5H2O); $1.5 \mathrm{mg} \mathrm{I} \mathrm{(as}$ $\mathrm{KI})$, and $0.15 \mathrm{mg} \mathrm{Se}$ (as Na2SeO3.5H2O).

\section{Tested product}

The ionized or chelated mineral mixture was obtained from a commercial company (Jino Biotech Inc., South Korea). According to the supplier's information, inorganic mineral ions were extracted effectively in ceramics (natural mineral) and the extractions of inorganic ions were maximized using hydrodynamic cavitation as mentioned by Zhou et al. 
(1997). The chelated mineral mixture was produced by mixing the ionized minerals with a natural extract. This natural extract was obtained by Bacillus fermentation of plants, such as wild grapes and prickly pear. This impure mineral mixture was purified using ion exchange membrane filters with micro pores. The water soluble ionized and chelated mineral mixture consisted of $\mathrm{Na}$ (1458.0mg), Mg (400mg), K (95.0 $\mathrm{mg}), \mathrm{Ca}(1430.0 \mathrm{mg}), \mathrm{Cu}$ (200mg), Zn (8.0mg), Fe (389.0mg), Si (180mg) P (18mg), Mn (28mg) Co (1.2 $\mathrm{mg}), \mathrm{Al}(125), \mathrm{S}(44.6 \mathrm{mg}), \mathrm{V}$ (13mg), and Se $(0.3 \mathrm{mg})$. These minerals were mixed in $1 \mathrm{~L}$ water and $0.5 \%$ of this water soluble mineral mixture was administered to the laying birds during the experimental period.

\section{Chemical Analysis}

Feed samples were ground to pass through a 1-mm screen, after which they were analyzed for $\mathrm{N}$ (method 968.06; AOAC, 2000), Ca (method984.01; AOAC, 1995), and $P$ (method 965.17; AOAC, 1995). Lysine was measured using an AA analyzer (Beckman 6300; Beckman Coulter Inc., Fullerton, CA) after a 24-h hydrolysis in $\mathrm{HCl}$ (Spackman et al., 1958). For the determination of Cys and Met, the samples were oxidized with performic acid overnight at $0^{\circ} \mathrm{C}$. Performic acid is an oxidizing reagent that convertsCys quantitatively to cysteic acid and Met to Met sulfone (Moore, 1963). Nitrogen was determined (Kjectec2300 Nitrogen Analyzer; Foss Tecator AB, Hoeganaes, Sweden), and CP was calculated as $\mathrm{N} \times 6.25$.

\section{Egg production and quality}

Hens were allowed ad libitum access to feed and water throughout the experimental period. Eggs were collected on a daily basis, and egg production was calculated as total number of eggs producted divided by the total number of days and hens. The rate of cracked eggs was also assessed.

In addition, egg quality was checked in weeks 1 , 2, 3, 4 and 5 of the experimental period. A total of 36 saleable eggs (no eggshell defects, cracks, or doubleyolks) were randomly collected from each treatment (three eggs per replicate) at 17:00 $\mathrm{h}$ and were used to determine egg quality at 20:00 h the same day. Eggshell breaking strength $\left(\mathrm{kg} / \mathrm{cm}^{2}\right)$ was evaluated using an Eggshell Force Gauge Model II (Robotmation Co., Tokyo, Japan). Egg weight, yolk color, yolk height, and Haugh units were evaluated using an Egg Multi Tester (Touhoku Rhythm Co., Tokyo, Japan). Finally, eggshell thickness was measured on the large end, equatorial region, and small end respectively using a Dial Pipe Gauge (Ozaki MFG. Co., Tokyo. Japan).

\section{Nutrient digestibility}

Laying hens were fed their respective diets containing chromic oxide $\left(\mathrm{Cr}_{2} \mathrm{O}_{3}\right.$ at $0.20 \%$ level) for 4 days prior to the collection period to determine nutrient digestibility. Whole excreta collection was performed daily for three days in week 5 and stored at $-20^{\circ} \mathrm{C}$ until further analysis. All excreta and feed samples were analyzed according to the AOAC procedures (AOAC, 2000)

\section{Blood profiles}

Blood samples were randomly collected from two layers per replicate (24 layers per treatment) from their wing veins using a sterilized needle at the end of the experiment. Blood samples were then transferred into a $\mathrm{K}_{3}$ EDTA vacuum tube (Becton Dickinson Vacutainer Systems, Franklin Lakes, NJ, USA). The samples for serum analyses were then centrifuged at 3,000 $\times \mathrm{g}$ for $15 \mathrm{~min}$, and an aliquot of $4 \mathrm{~mL}$ was stored at $-4^{\circ} \mathrm{C}$ until it was analyzed for Ca using colorimetry, and for $\mathrm{P}$, using phosphomolydate, in an automatic biochemistry modular analytic system (PE, Roche, Germany). Red blood cell (RBC), white blood cell (WBC), and lymphocyte counts in whole blood samples were determined using an automatic blood analyzer (ADVIA 120, Bayer, Tarrytown, NY, USA).

\section{$E$. coli and Salmonella isolation and enumeration}

At the end of the experiment, fecal samples were collected from six layers randomly selected from each replicate, pooled, and placed on ice for transportation to the lab. Excreta samples were processed at arrival according to method mentioned by Wang \& Kim (2011). One gram of the excreta sample pooled per replication was diluted with $9 \mathrm{~mL}$ of $1 \%$ peptone broth (Becton, Dickinson and Co., Rutherford, NJ) and homogenized. Viable counts of Salmonella and E.coli in the excreta samples were then conducted by plating serial 10 -fold dilutions (in 1\% peptone solution) onto MacConkey agar plates (Difco Laboratories, Detroit, $\mathrm{MI})$ and Salmonella-Shigella agar plates to isolate $E$. coli and Salmonella, respectively. The MacConkey agar and Salmonella Shigella agar plates were incubated for 24 hat $37^{\circ} \mathrm{C}$ under anaerobic conditions. Bacterial colonies were counted immediately after removal from the incubator.

\section{Statistical Analysis}

Data were analyzed according to a randomized block design using GLM procedures (SAS Inst. Inc., 
Cary, NC) and significant differences were examined by least significant different (LSD) test. The cage was used as the blocking criterion. Data variability is expressed as standard error of mean (SEM), and a probability level of $p<0.05$ was considered as statistically significant and a probability level of 0.1 or less was considered as tendency.

\section{RESULT AND DISCUSSION}

\section{Egg production and quality}

As shown in Table 2, egg production tended be higher in the birds supplemented with water soluble ionized or chelated mineral mixture compared with CON in week $1(p=0.08)$ and week $4(p=0.09)$. Harbaugh \& Sanford (1970) reported egg production per hen housed increased when optimal levels of zinc methionine were supplemented to layer diets. Also, $\mathrm{Zn}$ supplementation of 3,000-5,000 ppm from $\mathrm{ZnO}$ increased weight and feed intake in weanling pigs (Hahn \& Baker, 1993; Carlson et al., 1995; Lemieux et al., 1995). Pesti \& Bakalli (1998) reported the results of two layers' experiments in which egg production linearly increased as supplemental $\mathrm{Cu}$ from Cu sulfate pentahydrate increased from 0 to 125 and $250 \mathrm{mg} /$ $\mathrm{kg}$ diet. Xavier et al. (2004) also reported that that the use of organic Se, $\mathrm{Zn}$. and $\mathrm{Mg}$ combinations improved the performance and egg quality of brown layers during second laying cycle. Conversely, Sechinato et al. (2006) reported that there was no effect of organic minerals on the performance and egg production compared with inorganic minerals in 48- to 60-week-old layers. Likewise, Fernandes et al. (2008) noted that supplementation of organic trace minerals did not affect egg production or quality. The response to mineral supplementation depends on mineral concentration in the basal diet (Payane et al. 2005).

Cracked egg rate was not affected by the dietary supplementation with ionized or chelated watersoluble mineral mixture (Table 2). However, Hudson (2004) reported that feeding layers with Zn-amino acid complexes increased egg specific gravity and reduced amount of cracked eggs compared with inorganic $\mathrm{Zn}$ sources. Ceylan \& Scheideler (1999) also reported that the percentage of cracked eggs during processing was also reduced by the supplementation of zinc and manganese to the layer diets. Eggshell strength is influenced by copper-containing enzymes that provide collagen stability and strength (Underwood, 1977), but no effect on eggshell strength was observed in our study. More research is needed to clarify the effect of ionized or chelated minerals on eggshell strength and rate of cracked eggs.

The effects of ionized or chelated water-soluble mineral mixture on egg quality are shown in Table 3. Layers fed the T2 diet produced $(p<0.05)$ thicker eggshells than that compared with CON in week 4. However, Fernandes et al. (2008) did not find any positive effect of organic trace minerals on eggshell thickness, specific gravity, or cracked egg percentage. The improvement in eggshell thickness observed in the present experiment may be due to the interaction of trace minerals with calcium crystals during eggshell formation or to the catalytic properties of minerals that stimulate some key enzymes involved in the process of membrane or eggshell synthesis. In the current study, no effects $(p>0.05)$ of the treatments were observed on eggshell color, egg weight, yolk color, or eggshell strength during the experimental period.

Table 2 - The effects of ionized or chelated water-soluble mineral mixture on egg production and cracked egg rate in laying hens

\begin{tabular}{|c|c|c|c|c|}
\hline Items, \% & $\mathrm{CON}^{1}$ & $\mathrm{~T} 1{ }^{1}$ & $\mathrm{~T} 2^{1}$ & P-value \\
\hline \multicolumn{5}{|c|}{ Egg production } \\
\hline 41 wk & $94.35 \pm 0.29$ & $95.43 \pm 1.30$ & $95.79 \pm 0.60$ & 0.08 \\
\hline $42 w k$ & $95.24 \pm 0.0$ & $96.03 \pm 0.90$ & $96.12 \pm 0.90$ & 0.19 \\
\hline $43 w k$ & $94.55 \pm 0.61$ & $96.63 \pm 1.20$ & $96.45 \pm 0.59$ & 0.10 \\
\hline 44 wk & $94.94 \pm 0.30$ & $96.03 \pm 0.34$ & $95.86 \pm 0.59$ & 0.09 \\
\hline $45 w k$ & $94.74 \pm 0.61$ & $95.64 \pm 1.40$ & $96.85 \pm 0.91$ & 0.20 \\
\hline \multicolumn{5}{|c|}{ Cracked egg rate } \\
\hline $41 w k$ & $1.58 \pm 0.95$ & $1.25 \pm 0.02$ & $1.24 \pm 0.01$ & 0.70 \\
\hline $42 w k$ & $1.25 \pm 0.0$ & $1.04 \pm 1.30$ & $0.95 \pm 0.94$ & 0.91 \\
\hline 43 wk & $0.94 \pm 0.31$ & $0.83 \pm 0.96$ & $0.92 \pm 0.32$ & 0.95 \\
\hline 44 wk & $1.57 \pm 0.32$ & $1.24 \pm 0.62$ & $1.24 \pm 1.23$ & 0.86 \\
\hline 45 wk & $1.26 \pm 0.01$ & $1.05 \pm 1.32$ & $1.2 \pm 0.61$ & 0.93 \\
\hline
\end{tabular}

'Abbreviation: CON (basal diet + plain tap water), $\mathrm{T} 1$ (CON+0.5\% ionized mineral mixture in water, $\mathrm{pH} 3.0)$ and T2 (CON+0.5\% cheated mineral mixture in water, pH 3.0). 
Table 3 - Effects of ionized or chelated water-soluble mineral mixture on egg quality

\begin{tabular}{|c|c|c|c|c|}
\hline Items & $\mathrm{CON}^{1}$ & T11 & $\mathrm{T} 2^{1}$ & P-value \\
\hline \multicolumn{5}{|l|}{$41 w k$} \\
\hline Eggshell color & $12.2 \pm 1.2$ & $12.7 \pm 0.98$ & $12.6 \pm 1.23$ & 0.43 \\
\hline Egg weight, g & $59.48 \pm 3.6$ & $60.18 \pm 4.87$ & $59.07 \pm 4.03$ & 0.71 \\
\hline Yolk height, mm & $8.59 \pm 0.75$ & $8.81 \pm 0.83$ & $8.66 \pm 0.43$ & 0.62 \\
\hline Yolk color & $7.65 \pm 0.98$ & $8.15 \pm 0.93$ & $7.95 \pm 0.75$ & 0.22 \\
\hline Haugh Unit & $94.85 \pm 4.3$ & $94.9 \pm 4.3$ & $93.89 \pm 3.0$ & 0.67 \\
\hline Eggshell strength, kg/cm² & $3.61 \pm 0.55$ & $3.85 \pm 0.50$ & $3.79 \pm 0.78$ & 0.48 \\
\hline Eggshell thickness, $\mathrm{mm}^{-2}$ & $39.77 \pm 1.6$ & $40.35 \pm 2.06$ & $39.87 \pm 1.5$ & 0.55 \\
\hline \multicolumn{5}{|l|}{42 wk } \\
\hline Eggshell color & $12.1 \pm 1.02$ & $12.7 \pm 1.12$ & $12.8 \pm 1.32$ & 0.13 \\
\hline Egg weight, g & $59.68 \pm 2.69$ & $60.61 \pm 2.35$ & $59.91 \pm 2.21$ & 0.44 \\
\hline Yolk height, mm & $8.74 \pm 0.48$ & $8.72 \pm 0.84$ & $8.58 \pm 0.54$ & 0.67 \\
\hline Yolk color & $8.0 \pm 0.79$ & $8.25 \pm 0.79$ & $8.2 \pm 0.83$ & 0.63 \\
\hline Haugh Unit & $94.55 \pm 1.60$ & $95.37 \pm 1.72$ & $95.07 \pm 1.02$ & 0.16 \\
\hline Eggshell strength, $\mathrm{kg} / \mathrm{cm}^{2}$ & $3.68 \pm 0.34$ & $3.676 \pm 0.59$ & $3.77 \pm 0.55$ & 0.80 \\
\hline Eggshell thickness, $\mathrm{mm}^{-2}$ & $39.99 \pm 1.14$ & $40.48 \pm 1.03$ & $40.22 \pm 0.88$ & 0.39 \\
\hline \multicolumn{5}{|l|}{43 wk } \\
\hline Eggshell color & $12 \pm 0.94$ & $12.6 \pm 1.1$ & $12.4 \pm 1.31$ & 0.19 \\
\hline Egg weight, g & $58.95 \pm 2.5$ & $59.83 \pm 2.9$ & $60.28 \pm 2.81$ & 0.26 \\
\hline Yolk height, mm & $8.74 \pm 0.39$ & $8.54 \pm 0.68$ & $8.59 \pm 0.39$ & 0.45 \\
\hline Yolk color & $8.6 \pm 0.50$ & $8.35 \pm 0.59$ & $8.3 \pm 0.47$ & 0.14 \\
\hline Haugh Unit & $94.26 \pm 4.06$ & $95.71 \pm 3.91$ & $94.85 \pm 2.9$ & 0.51 \\
\hline Eggshell strength, $\mathrm{kg} / \mathrm{cm}^{2}$ & $3.53 \pm 0.36$ & $3.50 \pm 0.75$ & $3.65 \pm 0.71$ & 0.75 \\
\hline Eggshell thickness, $\mathrm{mm}^{-2}$ & $39.94 \pm 1.32$ & $40.28 \pm 1.15$ & $40.46 \pm 0.81$ & 0.35 \\
\hline \multicolumn{5}{|l|}{44 wk } \\
\hline Eggshell color & $12.4 \pm 0.74$ & $12.7 \pm 0.75$ & $12.5 \pm 1.23$ & 0.60 \\
\hline Egg weight, g & $59.67 \pm 3.47$ & $60.54 \pm 3.63$ & $60.99 \pm 3.68$ & 0.26 \\
\hline Yolk height, mm & $8.72 \pm 0.28$ & $8.66 \pm 0.67$ & $8.64 \pm 0.39$ & 0.86 \\
\hline Yolk color & $8.5 \pm 0.51$ & $8.65 \pm 0.58$ & $8.65 \pm 0.49$ & 0.62 \\
\hline Haugh Unit & $94.3 \pm 3.43$ & $94.9 \pm 3.78$ & $95.04 \pm 4.6$ & 0.74 \\
\hline Eggshell strength, $\mathrm{kg} / \mathrm{cm}^{2}$ & $3.64 \pm 0.42$ & $3.62 \pm 0.72$ & $3.76 \pm 0.79$ & 0.75 \\
\hline Eggshell thickness, $\mathrm{mm}^{-2}$ & $39.72^{b} \pm 0.83$ & $40.29^{\mathrm{ab}} \pm 0.75$ & $40.44^{a} \pm 0.68$ & 0.02 \\
\hline \multicolumn{5}{|l|}{45 wk } \\
\hline Eggshell color & $12.4 \pm 1.23$ & $12.4 \pm 1.35$ & $12.5 \pm 1.32$ & 0.97 \\
\hline Egg weight, g & $59.82 \pm 2.47$ & $60.65 \pm 2.99$ & $61.0 \pm 3.9$ & 0.37 \\
\hline Yolk height, mm & $8.64 \pm 0.43$ & $8.78 \pm 0.39$ & $8.59 \pm 0.40$ & 0.42 \\
\hline Yolk color & $8.5 \pm 0.76$ & $8.55 \pm 0.60$ & $8.65 \pm 0.49$ & 0.77 \\
\hline Haugh Unit & $95.11 \pm 2.97$ & $95.55 \pm 2.95$ & $95.33 \pm 3.12$ & 0.86 \\
\hline Eggshell strength, $\mathrm{kg} / \mathrm{cm}^{2}$ & $3.63 \pm 0.37$ & $3.71 \pm 0.54$ & $3.75 \pm 0.84$ & 0.82 \\
\hline Eggshell thickness, $\mathrm{mm}^{-2}$ & $39.68 \pm 2.19$ & $40.33 \pm 0.79$ & $40.59 \pm 0.55$ & 0.10 \\
\hline
\end{tabular}

'Abbreviation: CON (basal diet + normal tap water), $\mathrm{T} 1$ (CON+0.5\% ionized mineral mixture in water, $\mathrm{pH} 3.0)$ and $\mathrm{T} 2$ (CON+ $0.5 \%$ cheated mineral mixture in water, $\mathrm{pH} 3.0)$.

$a, b$ Means in the same row with different superscripts differ $(p<0.05)$.

In contrast, Paik (2001) observed that layers supplied feed containing only chelated zinc produced heavier eggs compared with those fed an organic tracemineral mixture of an association of organic zinc and manganese. Zinc plays an important role in poultry, particularly in layers, as a component of a number of metalloenzymes, such as carbonic anhydrase which is essential for eggshell formation in the shell gland (Scheideler, 2008). Other important zinc metalloenzymes in the hen include carboxypeptidases and DNA polymerases. These enzymes play important roles in the hens' immune response, in skin and wound healing, and in hormone production (testosterone and corticosteroids). Ceylan \& Scheideler (1999) reported significant positive effects of zinc and manganese supplementation from organic $\mathrm{Zn}$ and $\mathrm{Mn}$ sources on carbonic anhydrase activity levels in the shell gland of laying hens and a correlated improvement in eggshell percentage relative to egg weight. Increasing dietary calcium from $2.5 \%$ to $4.5 \%$ improved eggshell weight (Clunies et al. 2002). There are also evidences that feed additives that increase the availability of $\mathrm{Ca}$ 
and other minerals may also improve eggshell quality (Sątkiewicz, 2010). Klecker et al. (2002) found positive effects of the partial substitution of inorganic $\mathrm{Zn}$ and Mn sources by their organic forms on eggshell weight and eggshell thickness. Therefore, in our study, the improvement in eggshell thickness was possibly due to the higher mineral bioavailability, particularly of $\mathrm{Ca}$, or to their influence on enzymes that is responsible for eggshell synthesis.

\section{Nutrient digestibility}

Table 4 shows the effects of the tested mineral complex on nutrient digestibility. At the end of experiment, higher $(p<0.05) \quad$ Ca digestibility was obtained in layers fed the T1 diet compared with CON. No effects of the treatments on the digestibility of the dry matter, nitrogen, energy, or phosphorus were observed ( $p>0.05)$. Webb et al. (2005) reported that organic minerals chelated to small peptides have much greater bioavailability than their inorganic forms through increased selective transport of peptides at gut level. Calcium is absorbed across the gut wall in the ionized form and the solubility of the Ca source plays an important role in its absorption (Pak et al., 1989). The increased solubility of Ca in ionized form may be the reason of the increase in its digestibility in the present study.

Table 4 - Effects of ionized or chelated water-soluble mineral mixture on nutrient digestibility in laying hens

\begin{tabular}{lllll}
\hline Items, $\%$ & \multicolumn{1}{c}{$\mathrm{CON}^{1}$} & \multicolumn{1}{c}{$\mathrm{T}^{1}$} & \multicolumn{1}{c}{${ }^{1} 2^{1}$} & P-value \\
\hline Dry matter & $73.43 \pm 2.4$ & $74.66 \pm 2.9$ & $74.08 \pm 2.15$ & 0.68 \\
Nitrogen & $60.65 \pm 4.4$ & $62.37 \pm 5.01$ & $62.41 \pm 2.33$ & 0.67 \\
Gross Energy & $77.16 \pm 2.15$ & $78.26 \pm 2.43$ & $77.7 \pm 2.73$ & 0.68 \\
Ca & $51.15^{\mathrm{b}} \pm 3.3$ & $57.58^{\mathrm{a}} \pm 3.98$ & $55.27^{\mathrm{ab}} \pm 1.61$ & 0.004 \\
$\mathrm{P}$ & $44.56 \pm 8.1$ & $48.48 \pm 6.61$ & $47.31 \pm 2.98$ & 0.48 \\
\hline
\end{tabular}

${ }^{1}$ Abbreviation: CON (basal diet + normal tap water), $\mathrm{T} 1(\mathrm{CON}+0.5 \%$ ionized mineral mixture in water, $\mathrm{pH} 3.0)$ and $\mathrm{T} 2(\mathrm{CON}+0.5 \%$ cheated mineral mixture in water, $\mathrm{pH}$ 3.0).

${ }^{2}$ Standard error of mean.

$a, b$ Means in the same row with different superscripts differ $(p<0.05)$.

\section{Blood profiles}

The effect of the water-soluble mineral mixture on the layers' blood profiles is shown in Table 5 . Birds fed the T1 and the T2 diet presented higher $(p<0.05)$ blood Ca levels compared with those fed water with no mineral supplementation. On the other hand, WBC, RBC, and lymphocytes were not influenced by the water supplementation with the ionized or chelated mineral complex. It was suggested that the absorption and balance of plasma calcium, phosphorus, and magnesium levels improved with the dietary supplementation of $2.72 \mathrm{ppm}$ boron in Vitamin D-deficient rats (Hegsted et al., 1991). The potential reason for the increase in Ca absorption in the present study may be the bioavailability of minerals supplemented in the diet.

Table 5 - Effects of ionized or chelated water-soluble mineral mixture on blood profiles in laying hens

\begin{tabular}{|c|c|c|c|c|}
\hline Items & $\operatorname{CON}^{1}$ & $\mathrm{~T} 1^{1}$ & $\mathrm{~T}^{1}{ }^{1}$ & P-value \\
\hline WBC, $10^{3} / \mu \mathrm{L}$ & $165.7 \pm 8.96$ & $165.5 \pm 29.1$ & $162.8 \pm 22.6$ & 0.96 \\
\hline $\mathrm{RBC}, 10 \% / \mu \mathrm{L}$ & $1.65 \pm 0.05$ & $1.69 \pm 0.18$ & $1.64 \pm 0.13$ & 0.85 \\
\hline Lymphocyte, \% & $49.0 \pm 7.02$ & $50.3 \pm 4.64$ & $49.5 \pm 3.10$ & 0.89 \\
\hline $\mathrm{Ca}, \mathrm{mg} / \mathrm{dL}$ & $22.45^{b} \pm 2.08$ & $27.23^{\mathrm{a}} \pm 0.95$ & $27.7^{\mathrm{a}} \pm 2.08$ & 0.01 \\
\hline $\mathrm{P}, \mathrm{mg} / \mathrm{dL}$ & $4.58 \pm 0.50$ & $5.28 \pm 0.50$ & $5.20 \pm 0.50$ & 0.42 \\
\hline
\end{tabular}

'Abbreviation: CON (basal diet + normal tap water), $\mathrm{T} 1$ (CON+0.5\% ionized mineral mixture in water, $\mathrm{pH} 3.0)$ and $\mathrm{T} 2(\mathrm{CON}+0.5 \%$ cheated mineral mixture in water, $\mathrm{pH}$ 3.0). WBC: white blood cell, RBC: red blood cells

${ }^{2} \mathrm{~S}$ tandard error of means.

$a, b$ Means in the same row with different superscripts differ $(p<0.05)$.

\section{Excreta Salmonella and E. coli isolation and enumeration}

The effects of water-soluble mineral complex water supplementation on excreta Salmonella and $E$. coli isolation and enumeration are shown in Table 6 . Salmonella and E. coli counts in the excreta tended to be reduced ( $p=0.07, p=0.05$ respectively) in birds fed the T1 and T2 treatments compared with CON. Copper supplementation may also affect intestinal microflora and has been shown to affect the presence of bacteria in the litter (Johnson et al., 1985). Dietary calcium phosphate has a trophic effect on the intestinal microflora and strongly protects against Salmonella infection in rats (Bovee-Oudenhoden et al., 1997). The effect of $\mathrm{Zn}$ on the intestinal microflora resembles the mode of action suggested for antibiotic growth promoters (Hojberg et al., 2005). Hedemann et al. (2006) reported that feeding pigs the high dietary Zn concentrations mucin secretion in the cecum and colon, perhaps as a consequence of altered microbial activity in the large intestine. In the present study, our results indicate that mineral mixture supplementation led to reduction of E. coli and Salmonella counts compared with the control treatment. The observed trends of lower counts of these microorganisms may be due to the antibacterial activity of the supplemented mineral complex. Newman \& Cragg (2007) also reported that mineral clays could function as an inexpensive bactericidal compound against resistant bacterial pathogens. 
Table 6 - Effects of ionized or chelated water-soluble mineral mixture fecalSalmonella and E. coli counts

\begin{tabular}{lllll}
\hline Items, $\log 10 \mathrm{cfu} / \mathrm{g}$ & $\mathrm{CON}^{1}$ & $\mathrm{~T} 1{ }^{1}$ & $\mathrm{~T}{ }^{1}$ & P-value \\
\hline Salmonella & $2.4 \pm 0.14$ & $2.24 \pm 0.04$ & $2.19 \pm 0.09$ & 0.07 \\
E. coli & $6.5 \pm 0.12$ & $6.24 \pm 0.06$ & $6.2 \pm 0.19$ & 0.05 \\
\hline
\end{tabular}

'Abbreviation: CON (basal diet + normal tap water), T1 (CON+0.5\% ionized mineral mixture in water, $\mathrm{pH} 3.0)$ and $\mathrm{T} 2(\mathrm{CON}+0.5 \%$ cheated mineral mixture in water, $\mathrm{pH}$ 3.0).

${ }^{2}$ Standard error of means.

\section{CONCLUSION}

In conclusion, our results indicated that chelated or ionized mineral water supplementation significantly improved blood Ca level and improved Ca digestibility compared with the control treatment. Trends of higher egg production, and reduced excreta $E$. coli and Salmonella counts were also observed. Therefore, the water supplementation with a water-soluble mineral mixture showed partial benefits in laying hens, and suggests that the tested mineral mixture could be used as a substitute for antibiotics.

\section{ACKNOWLEDGEMENTS}

This work was supported by the Human Resource Training Program for Regional Innovation and Creativity through the Ministry of Education and National Research Foundation of Korea (NRF-2014H1C1A1067113).

\section{REFERENCES}

AOAC. Official method of analysis. 16th ed. Washington, DC; 1995.

AOAC. Official methods of analysis. 16th ed. Washington, DC; 2000.

Bovee-Oudenhoden IMJ, Termont DSML, Heidt PJ, Van der Meer R. Increasing the intestinal resistance of rats to the invasive pathogen Salmonella enteritidis: additive effects of dietary lactulose and calcium. Gut 1997:40:497-504

Carlson MS, Hill GM, Link JE, McCully GA, Rozeboom DW, Weavers RL. Impact of zinc oxide and copper sulfate supplementation on the newly weaned pig [abstr]. Journal of Animal Science 1995;73 (Suppl 1):72.

Ceylan N, Scheideler SE. Effects of the eggshell - 49, dietary calcium level and hen age on performance and egg shell quality. San Diego: Academic Press; 1999. p.267-275.

Clunies M, Parks D, Leeson S. Calcium and phosphorus metabolism and egg shell formation of hens fed different amounts of calcium. Poultry Science. 2002;71:482-489.

Decoux M, Manangi MK, Richards J, Wuelling B, Atwell C, Fisher P, Knight $C D$, Vazquez-Anon M, Carter S. Feeding laying hens the diets with supplemental chelated trace minerals improves immune response, shell quality and tibia breaking strength. St. Charles: Novus International; 2013.
Fernandes JIM, Murakami AE, Sakamoto MI, Souza LMG, Malaguido A Martins EN. Effects of organic mineral dietary supplementation on production performance and egg quality of white layers. Brazilian Journal of Poultry Science. 2008;10:59-65.

Hahn JD, Baker DH. Growth and plasma zinc responses of young pigs fed pharmacologic levels of zinc. Journal of Animal Science 1993;71:30203024.

Harbaugh DD, Sanford PE. The effect of various levels of zinc-methionie supplement on flock performance, egg size and shell quality [abstr]. Poultry Science 1970;49:1393

Hedemann MS, Jensen BB, Poulsen HD. Influence of dietary zinc and copper on digestive enzyme activity and intestinal morphology in weaned pigs. Journal of Animal Science 2006;84:3310-3320

Henry PR, Ammerman CB, Littell RC. Relative bioavailability of manganese from manganese in methionine complex and inorganic sources for ruminants. Journal of Dairy Science 1992;75:3473-3478.

Hegsted M, Keenan MJ, Siver F, Wozniak P. Effect of boron on vitamin D deficient rats. Biological Trace Element Research 1991;28:243-255.

Hojberg O, Canibe N, Poulsen HD, Hedemann MS, Jensen BB. Influence of dietary zinc oxide and copper sulfate on the gastrointestinal ecosystem in newly weaned piglets. Applied Environmental Microbiology 2005; 71:2267-2277

Hudson BP, Dozier WA, Wilson JL, Sander JE, Ward TL. Reproductive performance and immune status of caged broiler breeder hens provided diets supplemented with either inorganic or organic sources of zinc from hatching to 65 week of age. Journal of Applied Poultry Research 2004;13:349-359.

Johnson EL, Nicholson JL, Doerr JA. Effect of dietary copper on litter microbial population and broiler performance. British Journal of Poultry Science 1985; 26:171-177.

Klecker D, Zeman L, Jelinek P, Bunesova A. Effect of manganese and zinc chelates on the quality of eggs. Acta Universitatis Agriculturae et Silviculturae Mendelianae Brunensis 2002;50:59-68.

Lemieux FM, Ellison LV, Ward TL, Southern LL, Bidner TD. Excess dietary zinc for pigs weaned at 28 days [abstr]. Journal of Animal Science 1995; 73 (Suppl. 1):72

Moore S. On the determination of cystine as a cysteic acid. Journal of Biological Science 1963;238:235-237.

Newman DJ, Cragg GM. Natural products as sources of new drugs over the last 25 years. Journal of Natural Products 2007;70:461-77.

NRC. Nutrient requirements of poultry. $9^{\text {th }}$ rev. ed. Washington: National Academy Press; 1994

Paik IK. Application of chelated mineral in animal production. AsianAustralasian Journal of Animal Science 2001;14:191-198.

Pak CYC, Poindexter J, Finlayson B. A model system for assessing physicochemical factors affecting calcium absorbability from the intestinal tract. Journal of Bone Mineral Research. 1989;4:119-127.

Payne RL, Lavergne TK, Southern LL. Effect of inorganic versus organic selenium on hen production and egg selenium concentration. Poultry Science 2005;84:232-237.

Pesti GM,Bakalli RI. Studies on the feeding cupric sulfate pentahydrate to laying hens on egg cholesterol content. Poultry Science 1998;77:15401545

Roland Sr. DA. Research note: egg shell problems: estimates of incidence and economic impact. Poultry Science.1988;67:1801-1803. 
Rutz F, Amciuti MA, Rech JL, Rossi P. The advantages of organic minerals in poultry diets. Feeding Times 2004;9:22-23.

Satkiewicz S, Koreleski J, Arczewska A. Laying performance and eggshell quality in laying hens fed diets supplemented with prebiotics and organic acids. Czech Journal of Animal Science 2010;55:294-306.

Scheideler SE. Trace mineral balance in poultry. Proceedings Midwest Poultry Federation Convention; 2008; St. Paul, Minnesota. USA

Sechinato AS, Albuquerque R, Nakada S. Effects of diet supplementation with organic trace minerals on production of laying hens. Brazilian Journal Veterinary Research Animal Science. 2006;43:159-166.

Spackman DH, Stein WH, Moore S. Automatic recording apparatus for use in the chromatography of amino acids. Analytical Chemistry 1958;30:1190-1206

Tim O'Shea DC. Minerals. Part III. Dynamic chiropractic. 1998. v. 16.

Available from: http://www.chiroweb.com/archives/16/25/18.html.

Underwood JE. Trace elements in human and animal nutrition. London: Academic Press; 1977. p.85

Underwood EJ, Suttle NF. The mineral nutrition of livestock. 3rd ed. Wallingford: CABI; 1999
Webb KE, Wong EA, Pan YX, Chen H, Poole CA, Van L, Klang JE. The role of peptides in absorption pathways. In: Taylor-Pickard JA, Tucker LA, editors. Redefining mineral nutrition. Nottingham: Nottingham University Press; 2005. p.197-225.

Wang JP, Kim IH. Effect of caprylic acid and Yuccaschidigera extract on production performance, egg quality, blood characteristics, and excreta microflora in laying hens. British Journal of Poultry Science 2011;52:711-717.

Ward JD, Spears JW, Kegley EB. Bioavailability of copper proteinate and copper carbonate relative to copper sulfate in cattle. Journal of Dairy Science 1996;79: 127-132.

Xavier GB, Rutz F, Dionello NJL, Arruda JS, Pan EA. Performance of layers fed diets containing organic selenium, zinc and manganese, during a second cycle of production. Proceedings of the 20th Annual Symposium on Biotechnology in the feed industry; 2004; Lexington, Kentucky. USA. p.19.

Zhou ZA, Xu Zhenghe, Finch JA, Hu H, Rao SR. Role of hydrodynamic cavitation in fine particle flotation. International Journal of Mineral Processing 1997;51:139-149. 